\title{
The effect of manual and mechanical stimulation on oxytocin release and milking characteristics in Holstein cows milked 3 times daily
}

\author{
Rick D. Watters, ${ }^{* 1}$ Rupert M. Bruckmaier, † Heather M. Crawford,‡ Norm Schuring, $¥$ Ynte H. Schukken,§ \\ and David M. Galton\# \\ *Quality Milk Production Services, Department of Population Medicine and Diagnostic Sciences, College of Veterinary Medicine, \\ Cornell University, Ithaca, NY 14853 \\ †Veterinary Physiology, Vetsuisse Faculty, University of Bern, CH-3001 Bern, Switzerland \\ ‡GEA Farm Technologies, Naperville, IL 60563 \\ §Department of Population Medicine and Diagnostic Sciences, College of Veterinary Medicine, Cornell University, Ithaca, NY 14853 \\ \#Department of Animal Science, College of Agriculture and Life Sciences, Cornell University, Ithaca, NY 14853
}

\begin{abstract}
Prestimulation administered to a cow before attachment of the milking unit has historically been performed manually. Development of innovative milking technology has allowed manual stimulation to be replaced by mechanical forms of stimulation. Holstein cows $(\mathrm{n}=30)$ were enrolled in a crossover design to determine the effect of manual stimulation (forestripping and drying) and high-vibration pulsation on oxytocin profiles, milk yield, milk flow rates, incidence of delayed milk ejection causing bimodal milk flow curves, and residual milk in Holstein cows milked 3 times daily $(3 \times)$. All cows were subjected to all treatments. Cows received manual (forestripping and drying) or mechanical (high-vibration pulsation) stimulation along with lag times of 0,30 , or $90 \mathrm{~s}$ for 21 consecutive milkings. Forestripping involved the manual removal of 2 streams of milk from each teat and drying of the teats. High-vibration pulsation involved increasing the pulsation cycles from 60 to 300 pulses/min and reducing the vacuum in the pulsation chamber to $20 \mathrm{kPa}$. The 5 treatments were (1) immediate attachment of the milking machine under normal pulsation (T0); (2) dip plus forestrip and drying with 30-s lag time (FD30); (3) dip plus forestrip and drying with 90-s lag time (FD90); (4) high-vibration pulsation for $30 \mathrm{~s}$ (HV30); and (5) high-vibration pulsation for $90 \mathrm{~s}$ (HV90). Milk yield per milking averaged $14.0 \mathrm{~kg}$ and was significantly different among treatments; however, the maximum difference detected among treatments was $0.8 \mathrm{~kg} /$ milking. Milking unit on-time, which represents the time when the milking unit is under normal pulsation and harvesting milk (excluding the high-vibration pulsation time of 30 or $90 \mathrm{~s}$ ), was shortest $(245 \mathrm{~s})$ for cows subjected to 90
\end{abstract}

Received May 6, 2014

Accepted November 10, 2014.

${ }^{1}$ Corresponding author: rdw32@cornell.edu s of high-vibration pulsation (HV90) and ranged from 256 to $261 \mathrm{~s}$ for all other treatments. Milk harvest may have begun during high-vibration pulsation; however, only 0.13 and $0.32 \mathrm{~kg}$ of milk was harvested during high-vibration pulsation for HV30 and HV90, respectively. The incidence of bimodal milk curves was lowest for FD90 (7\%) and highest for T0 (21\%). The somatic cell count was $<72 \times 10^{3}$ cells $/ \mathrm{mL}$ for all treatments. Residual milk obtained by giving 10 IU of oxytocin in the jugular vein followed by 2 min of milking unit attachment represented 12 to $14 \%$ of the total milk and did not differ among treatments. Endogenous oxytocin profiles peaked between 12.4 and $18.3 \mathrm{pg} / \mathrm{mL}$ for all treatments, and the peak occurred sooner in manually stimulated cows; however, we detected no difference in oxytocin concentration beyond 2 min after milking unit attachment. High-vibration pulsation elicited a similar oxytocin release when taking the start time of stimulation from manual stimulation or high vibration into consideration. Forestripping for visual observation of milk combined with the use of high-vibration stimulation may reduce variation in the milking routine. A predetermined lag time with minimal variation may be achieved via the time spent in high-vibration stimulation instead of a lag period dictated by milking personnel.

Key words: mechanical stimulation, premilking routine, lag time, milking unit on-time

\section{INTRODUCTION}

Initiation of milk ejection from the alveolar tissue is necessary to harvest the majority of milk from dairy cows, whereas a small, cisternal portion of milk can be harvested without any form of stimulation (Bruckmaier et al., 1994). The premilking routine is the main method used to elicit the milk ejection reflex that starts the expulsion of the alveolar milk fraction. The initiation of the cascade of events involved in the milk ejection 
reflex has historically been achieved via contact with a liner, by suckling of the calf, or through milk stripping by the human hand (Bruckmaier and Blum, 1996). Another form of stimulation comes from the interaction of the milking machine liner and the teat; this stimulation is maintained throughout the milking procedure while the milking unit is attached (Bruckmaier et al., 1997). Even without proper prestimulation before attachment of the milking unit, the alveolar fraction of milk will eventually be harvested; however, an interruption in milk flow may be observed as the cisternal fraction is removed before alveolar milk expulsion. With the advancement of milking technology and the introduction of milking robots, forms of stimulation other than the human hand have been used. Current technology in robotic milking systems uses mechanical stimulation as an attempt to initiate the release of oxytocin (Schams et al., 1984). Forms of mechanical stimulation that have been used are rotating brushes, different forms of pulsation, and simply the attachment of the milking unit in the milk mode. The attachment of the milking unit in the milking phase is a form of stimulation to which the pressure-sensitive neural receptors on the teat will respond. The use of vibrating pulsation at 300 cycles/ min with a maximum vacuum level of 20 to $22 \mathrm{kPa}$ in the pulsation chamber (keeping the liner closed) has also been investigated. Worstorff et al. (1987) investigated the use of a high-cycle and low-vacuum pulsation (300 cycles/60 s at 20-22 kPa) compared with manual stimulation and determined that vibration stimulation was an adequate method to cause the ejection of milk from the alveolar region. The type of liner used in conjunction with vibration stimulation (300 cycles/60 s) is also known to affect milk flow rates (Karch et al., 1988).

Manual stimulation of the teat for 15,30 , or $45 \mathrm{~s}$ followed by either 30 or $45 \mathrm{~s}$ of lag time causes a similar and unchanged oxytocin release throughout milking (Kaskous and Bruckmaier, 2011). When a lag time of 90 or $120 \mathrm{~s}$ and forestripping were involved, $>60 \%$ of milk was harvested in the first $2 \mathrm{~min}$ of unit on-time for late-lactation cows. When the degree of udder filling was $<40 \%$, a lag time of $45 \mathrm{~s}$ decreased unit on-time independent of how long tactile stimulation took place (Kaskous and Bruckmaier, 2011). Recent data indicated that when lag time is $>60 \mathrm{~s}$ in Holstein cows milked $3 \times$ daily, a reduction in milking unit on-time is seen in late-lactation cows (Watters et al., 2012). Weiss and Bruckmaier (2005) reported that a shortened (20-40 s) prep-lag time would increase the number of cows per milking stall in the case of milking cows with full udders in early lactation, whereas a prolonged (90 s) prep-lag time might be beneficial when milking cows in later lactation with udders at a low degree of filling.
Improper milking techniques may prevent the complete harvest of alveolar milk from the mammary gland. Milk remaining in the alveolar fraction after completion of milking is referred to as "residual milk" and this fraction may represent around $10 \%$ of the total milk (Turner, 1955; Goff and Schmidt, 1967; Negrão and Marnet, 2006). Residual milk may be evaluated by providing a supraphysiological amount of exogenous oxytocin through intravenous injection. Total milk stored in the udder can be determined by adding the milk yield from normal milking and the obtained residual milk. It has been reported that first-lactation cows have less residual milk compared with older cows (Schmidt, 1972). The use of brushes or vibration stimulation in a robotic milking system did not improve residual milk, which was between 14.8 and $15.9 \%$ of total milk (Macuhova et al., 2003), and these methods can therefore be defined as sufficient to elicit normal milk ejection compared with conventional milking.

Previous research has tested and analyzed highvibration pulsation; however, the parameters used to evaluate the outcomes of this form of stimulation were generally limited and did not include, for example, the evaluation of residual milk, milk harvest during highvibration pulsation, incidence of bimodal milk flow curves, oxytocin profiles, or milk quality. In addition, the use of high-vibration pulsation has not been evaluated in high-producing Holstein cows milked $3 \times$ daily.

Therefore, the objective of this experiment was to determine if high-vibration pulsation without any form of manual stimulation before harvest of milk is an adequate form of stimulation for Holstein cows milked $3 \times$ daily in a conventional parlor. We were interested in defining the adequacy of stimulation using milk flow curves, plasma oxytocin profiles, residual milk, and milk quality using several manual and milking machineinduced premilking routines for Holstein cows milked $3 \times$ daily.

\section{MATERIALS AND METHODS}

\section{Cows and Treatments}

Holstein cows $(\mathrm{n}=30)$ were selected from the 500cow dairy herd at the Cornell University Teaching and Research dairy facility (Ithaca, NY). Cows were milked $3 \times$ daily in a dedicated research parlor, housed in a 4-row freestall barn, and fed a TMR that either met or exceeded NRC (2001) requirements. Pen size was 30 cows for the cows enrolled in the study. The experiment was conducted from March through May 2010. All cows assigned to the study had 4 functioning quarters, no recorded incidence of clinical mastitis during the current lactation, and were less than 350 DIM at the time 
of enrollment. Cornell University's Institutional Animal Care and Use Committee approved the experimental protocol.

The trial was a randomized crossover design with 5 treatments, 5 periods, and 6 cows per treatment phase (n $=30 \mathrm{cows}$ ). Each treatment was performed at the same time and for 21 consecutive milkings before the cows were reassigned to another treatment. The treatments involved manual and mechanical forms of prestimulation and 3 lag times. The prestimulation methods were forestripping (2 streams of milk per teat) and drying, attachment of the milking unit with normal pulsation, or attachment of the milking unit with high-vibration pulsation. Lag times were determined from first tactile stimulus until milking machine was in milk mode; the 3 lag times were 0,30 , and $90 \mathrm{~s}$. The first tactile stimulus for manual stimulation was forestripping 2 streams of milk from each teat; for mechanical stimulation, the first stimulus was considered the attachment of the milking unit. Mechanical pulsation was performed either by the milking machine under normal milking conditions or by StimoPuls pulsation (StimoPuls, GEA Farm Technologies, Bönen, Germany). StimoPuls is a pulsation process that increases the pulsation cycles from 60 to 300 cycles per minute while maintaining a vacuum level of $20 \mathrm{kPa}$ in the pulsation chamber. Simultaneously, full vacuum (40-42 $\mathrm{kPa}$ ) in the liner and outside air pressure in the pulsation chamber are used to keep the liner closed and avoid harvest of milk during prestimulation. The 5 treatments were immediate attachment of milking unit with no lag time (T0), premilking teat disinfection (dip) with forestripping and drying with a lag of $30 \mathrm{~s}$ (FD30), dip plus forestripping and drying with a lag of $90 \mathrm{~s}$ (FD90), immediate attachment of milking unit with $30 \mathrm{~s}$ of StimoPuls pulsation (HV30), and immediate attachment of milking unit with $90 \mathrm{~s}$ of StimoPuls pulsation (HV90). All cows received all treatments in an order determined for each cow by a restricted randomization based on a table of random numbers. When the cow entered the milking parlor, each teat in the case of FD30 and FD90 was forestripped with expulsion of 2 streams of milk and dipped. At the time of the first forestrip, a stopwatch was started to keep track of lag time. At $10 \mathrm{~s}$ before the end of the desired lag time, cows' teats were dried and the milking unit was subsequently attached. The milking units were attached immediately after cows entered the milking parlor for mechanical stimulation in treatment groups T0, HV30, and HV90, with no manual stimulation of any form.

\section{Milking Equipment}

Cows were milked $3 \times$ daily in a double- 5 , low-line, herringbone parlor (GEA Farm Technologies). The sys- tem operating vacuum was $44 \mathrm{kPa}$, such that the claw vacuum was between 40 and $42 \mathrm{kPa}$. The pulsator had a pulsation rate of 60 cycles/min and a milk-to-rest ratio of 65:35. The milking claw had a volume of $300 \mathrm{~mL}$ (Classic 300, GEA Farm Technologies) and was used with a rubber liner that had a touchpoint of $11.9 \mathrm{kPa}$ (liner 086, GEA Farm Technologies). Teat cup removal occurred automatically when milk flow decreased to less than $1 \mathrm{~kg} / \mathrm{min}$.

\section{Data Acquisition}

During both the adaptation (milkings 1 to 9 ) and data-collection phases (milkings 10 to 21), cow and milking data were gathered on farm by using herdmanagement software (DairyComp 305, Valley Agricultural Software, Tulare, CA; DairyPlan C21, GEA Farm Technologies). For treatment groups T0, FD30, and FD90, milking unit on-time was defined as the time between unit attachment and unit removal. For treatments HV30 and HV90, milking unit on-time did not include the high-vibration pulsation time because the high-vibration pulsation time is considered a method of stimulation, not a form of milk harvest. Cows in treatments HV30 and HV90 had high-vibration stimulation during the first 30 and $90 \mathrm{~s}$ of milking unit attachment; therefore, to determine milk harvested during the first 2 min of milking for treatment HV30 and HV90, milk production was accumulated for 150 and $210 \mathrm{~s}$, respectively.

Bimodal milk curves indicating delayed milk ejection were determined by DairyPlan software (DairyPlan C21, GEA Farm Technologies). A bimodal milk curve was declared when milk flow increased to a peak and then decreased, followed by a second milk flow increase (Figure 1). These changes had to occur within the first $60 \mathrm{~s}$ after milk yield exceeded $500 \mathrm{~g}$ to be declared a bimodal milk curve. The value obtained from the difference of the milk flow peak minus the milk flow nadir was then divided by the peak milk flow value. If the value was $<72 \%$, then a bimodal milk curve was considered to have occurred: [(high flow - low flow) $\times 100] /$ high flow $>72$. The first peak of milk flow indicates cisternal milk, which is readily available for harvest before the release of oxytocin. The second peak of milk flow represents the flow of alveolar milk, which requires the presence of oxytocin for milk ejection.

\section{Sampling and Analysis}

Milk samples were collected during the last milking of the data-collection phase of each period (milking number 21) via an inline milk collection device. The milk collection device was connected to the milking sys- 


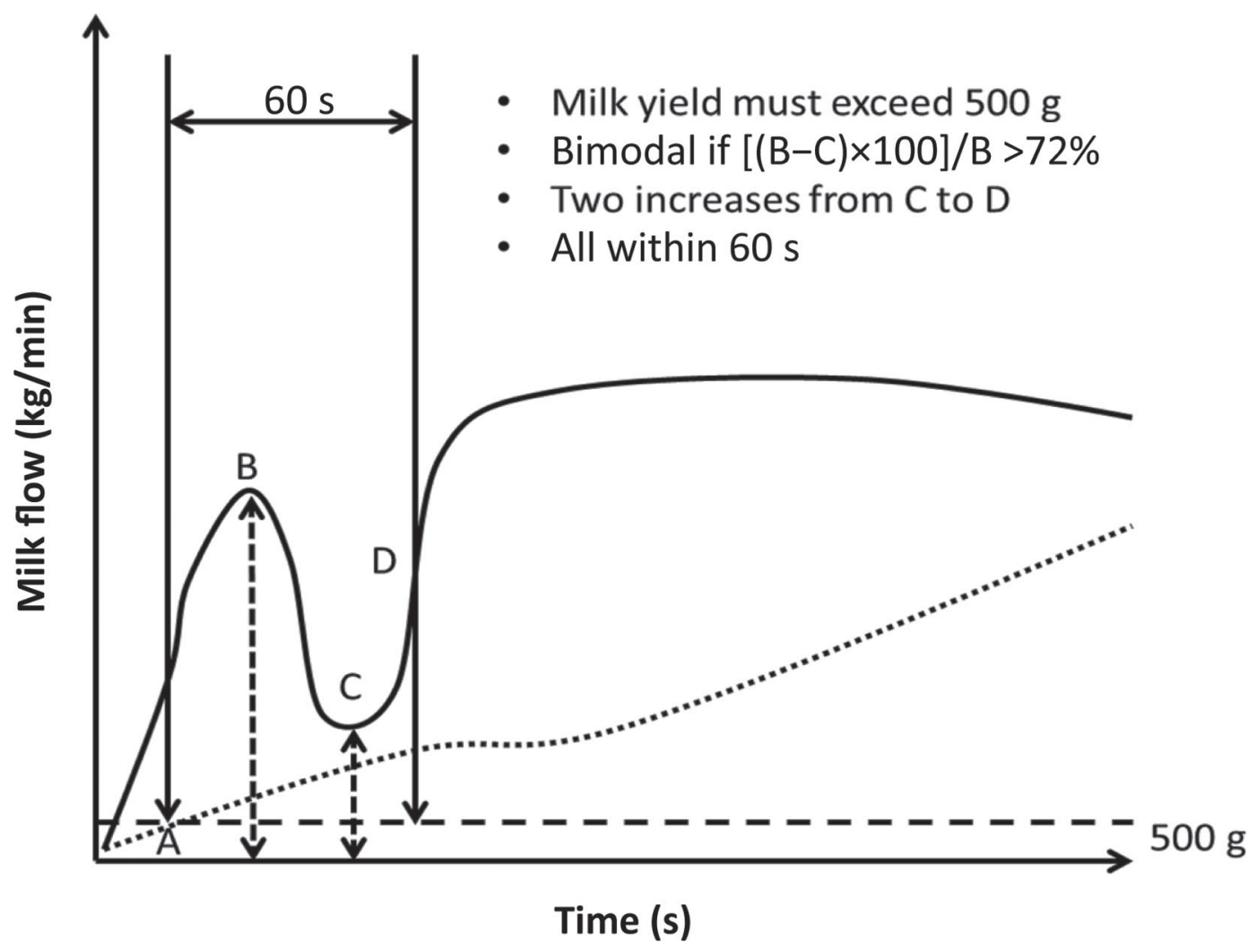

Figure 1. Illustration of a bimodal milk curve for a cow. The solid lines represent milk flow when a bimodal milk curve is declared; the dotted line represents total milk yield. The 2 vertical lines represent the 60 -s period when the milk flow curve is evaluated for bimodality. $\mathrm{A}=$ point at which milk yield reaches $500 \mathrm{~g} ; \mathrm{B}=$ peak milk flow during the $60 \mathrm{~s}$ after milk yield exceeds $500 \mathrm{~g}$; $\mathrm{C}=$ nadir in milk flow after peak milk flow achieved; and $\mathrm{D}=$ second increase in milk flow after nadir and during defined $60 \mathrm{~s}$.

tem to obtain a proportional sample of milk throughout the milking. A duplicate milk sample was taken from each milk sampler after the milking unit detached. The duplicate milk samples were put on ice. The milk samples were taken to a laboratory for SCC and plate loop count (PLC) analysis.

Milk analysis began within $24 \mathrm{~h}$ of harvesting the sample, and all samples were held between 0 and $4.4^{\circ} \mathrm{C}$ until they were analyzed. Milk samples were heated in a water bath until they reached 37 to $38^{\circ} \mathrm{C}$, at which time they were analyzed by the Fossomatic 5000 (Foss, Hillerød, Denmark). An hourly control sample with a known SCC between 500 and 800 cells $/ \mathrm{mL}$ was analyzed. The known samples were used to determine the SCC of these samples through direct microscopic somatic cell count. The instrument was calibrated to these reference samples (of raw bovine milk) and the samples were used to ensure the Fossomatic 5000 was functioning properly.

Raw milk samples were analyzed for bacteria count via the PLC methodology. The PLC is determined in the same manner as an SPC except the PLC uses a different apparatus, as outlined within section 21 of FDA-2400 (Northeimer, 2001).
A unilateral venous catheter (Dural $100 \mathrm{~cm} \times 1.0$ $\mathrm{mm}$ i.d. $\times 1.5-\mathrm{mm}$ o.d.) was inserted in the jugular vein of conscious cows by percutaneous venipuncture. Jugular catheters were inserted into 2 cows from each treatment $(\mathrm{n}=10)$ group after the seventh milking of each treatment phase. During the tenth milking of each treatment phase, blood samples were taken from each of the catheterized cows. All blood samples were collected in the same research parlor. As much as possible, we attempted to prevent stress and negative interactions with the catheterized cows that might result in changes in oxytocin secretion. Blood samples $(10 \mathrm{~mL})$ were harvested from the jugular catheter at $-5,0,1,2,4,5,8,9,10,11$, and $30 \mathrm{~min}$ relative to milking unit attachment time. Whole blood was collected in EDTA tubes and placed on ice before being centrifuged at $1,500 \mathrm{~g}$ for $20 \mathrm{~min}$ at $4^{\circ} \mathrm{C}$. Plasma from each blood vial was split into duplicates and frozen at $-20^{\circ} \mathrm{C}$ until analysis. Plasma oxytocin was determined by radioimmunoassay according to the assay developed for cattle (Schams, 1983). Extraction with SEP-PAK C18 cartridges (Waters Corp., Milford, MA) was used. Iodine $^{125}$ was used to label the oxytocin, and results are reported in picograms per milliliter. 
At $8 \mathrm{~min}$ after the start of milking, an i.v. injection of oxytocin ( $1 \mathrm{~mL}, 10 \mathrm{IU}$; VetOne, Boise, ID) was administered to each cow with a jugular catheter. All teat cups were automatically detached under normal milking conditions before the injection of oxytocin. At exactly $60 \mathrm{~s}$ after administration of the oxytocin, the milking unit was reattached for $120 \mathrm{~s}$. The milk weight was recorded at the time of oxytocin administration and again after milking $120 \mathrm{~s}$. The difference between these 2 weights was defined as residual milk.

\section{Statistical Analysis}

Statistical analysis was performed for milk yield, milking unit on-time, incidence of bimodal milk curves, average milk flow rate, percentage of milk in first 2 min, residual milk, oxytocin profiles, SCC, and PLC. All values are reported as least squares means \pm standard error (LSM $\pm \mathrm{SE}$; from SAS Institute, 1999) unless otherwise noted. Data were analyzed as repeated measures using the Proc Mixed procedure. Somatic cell counts and bacterial count (PLC) data were log-transformed for normalization. A $\log _{10}$ transformation was chosen and normality was investigated by use of the Kolmogorov-Smirnov statistic. Log-transformed data were used for statistical comparisons; however, the actual (inverse transformed) or raw values are presented. The fixed effects in the final models were, depending on the model, milk yield, average milk flow rate, stimulation method, lag time, the interaction of stimulation and lag time, period, and a complex error term. Fixed effects were included in the different models where these were relevant. For example, milk yield was (obviously) not included in the regression model in which the outcome variable was milk yield but was included in the model in which the outcome was unit on-time. The complex error term consisted of a correlation component reflecting within-cow correlation due to repeated measures and an independently normally distributed error term. Significant differences were declared at $P<0.05$ for main effects. There was a theoretical maximum of 1,800 milkings to be analyzed during the data-collection period and, of those, 1,719 milkings were used in the analysis. Milkings were removed from the analysis if the milk yield at a given milking was $<4 \mathrm{~kg}$ or if the milking unit on-time was $<120$ or $>420$ s.

\section{RESULTS AND DISCUSSION}

Pretrial data were gathered for the cows enrolled in the experiment, including the following: matureequivalent 305-d milk yield, milk yield per milking, DIM, parity, milking unit on-time, and average flow rate (Table 1 ). The mature-equivalent $305-\mathrm{d}$ milk yield
Table 1. Pretrial data for 30 cows assigned to treatments

\begin{tabular}{lrr}
\hline Variable & Mean & \multicolumn{1}{c}{ SE } \\
\hline Parity & 2.0 & 0.2 \\
DIM & 163.4 & 13.1 \\
Milk yield/milking (kg) & 15.0 & 0.4 \\
Milking unit on-time (s) & 266.4 & 6.8 \\
Average milk flow rate $(\mathrm{kg} / \mathrm{min})$ & 3.8 & 0.1 \\
\hline
\end{tabular}

of cows enrolled in the study was $13,533 \mathrm{~kg}$. The cows were in their first to sixth lactation and DIM ranged from 70 to $300 \mathrm{~d}$ at the time of enrollment. Milking unit on-time immediately before the trial ranged from 200 to $344 \mathrm{~s}$, and the average milk flow rate before the start of the study ranged from 1.8 to $5.2 \mathrm{~kg} / \mathrm{min}$.

The mean milking unit on-time for all treatments was $257 \pm 2.0 \mathrm{~s}$ (Table 2). Milking unit on-time was shortest for HV90 (245 s) and this was significantly different $(P<0.05)$ from all other treatments. Kaskous and Bruckmaier (2011) indicated that lag time had no effect on milking unit on-time when proportion of udder filling was $>40 \%$; however, increasing the lag time from 0 to 30,45 , or $60 \mathrm{~s}$ independent of stimulation time reduced the unit on-time when the degree of udder filling was $<40 \%$. Sandrucci et al. (2007) found the shortest milking unit on-time when lag times were between 1 and $60 \mathrm{~s}$, whereas Watters et al. (2012) reported that when the lag time was $>60 \mathrm{~s}$, milking unit on-time decreased in late-lactation cows. Milking unit on-time was significantly decreased $(P<0.05)$ when $60 \mathrm{~s}$ of vibration stimulation was compared with $60 \mathrm{~s}$ of manual stimulation (332 s vs. 350 s; Karch et al., 1988). Sagi et al. (1980b) reported that high-vibration pulsation resulted in the highest milking unit on-time compared with no stimulation, manual stimulation, or stimulation by positive pressure; however, those authors did not state whether time spent in the stimulation phase was included in unit on-time. In their study, the difference in unit on-time between manual stimulation and high-vibration pulsation was $60 \mathrm{~s}$ and high-vibration pulsation was turned on for $60 \mathrm{~s}$; therefore, it is possible that unit on-time was similar between mechanical and manual stimulation (Sagi et al., 1980b). Our observations in the current experiment are in agreement with Weiss and Bruckmaier (2005) that milking unit on-time was longest for $90 \mathrm{~s}$ of vibration stimulation when the stimulation time of $90 \mathrm{~s}$ was included in the milking unit on-time. As shown in our experiment, milking unit on-time may be lower in the case of HV90 when the $90 \mathrm{~s}$ spent in stimulation phase is not counted as part of the unit on time. Because only $0.32 \mathrm{~kg}$ of milk was harvested during the high-vibration stimulation phase, it may be argued that the $90-\mathrm{s}$ stimulation phase is not part of the process of milk harvesting but a true 
replacement of manual stripping and the subsequent waiting time until unit attachment.

The proportion of milk harvested in the first $2 \mathrm{~min}$ was $48.0 \pm 0.9 \%$ for all treatments combined. However, this differed significantly between each of the treatments $(P<0.05)$; the greatest difference was between HV90 and T0 (57.6 \pm 1.1 and $40.4 \pm 1.1$, respectively), representing the highest and lowest values (Table 2). Recent data also indicate that when lag time was 0 $\mathrm{s}$, the lowest percentage of milk was harvested in the first $2 \min (<45 \%)$, independent of stage of lactation (Watters et al., 2012). However, when lag time was 90 to $240 \mathrm{~s}, 48$ to $53 \%$ of milk was harvested during the first 2 min for early- to mid-lactation cows compared with 56 to $62 \%$ for late-lactation cows (Watters et al., 2012). Milk harvested in the first 2 min of milking (under normal milking pulsation) was $45.5 \% \pm 1.0 \%$ and $57.6 \% \pm 1.0 \%$ for HV30 and HV90 (Table 2). The amount of milk harvested during high-vibration pulsation (30 and $90 \mathrm{~s}$ for HV30 and HV90) was $0.13 \pm 0.03$ and $0.32 \pm 0.1 \mathrm{~kg}$, representing 1.2 and $2.2 \%$ of the total milk harvest, respectively. Removing the amount of milk harvested during high-vibration pulsation from the milk harvested during 150 and $210 \mathrm{~s}$ for HV30 and HV90 decreased the milk harvested to $44.3 \%$ and $55.3 \%$ for HV30 and HV90, respectively. The data clearly indicate that the greatest percentage of milk is harvested in the first $2 \mathrm{~min}$ when the stimulation or lag time is equal to $90 \mathrm{~s}$ in cows milked 3 times daily.

Mean milk production for all treatments was $14.0 \pm$ $0.4 \mathrm{~kg} /$ milking (Table 2). The highest milk yield was $14.5 \pm 0.3 \mathrm{~kg} /$ milking (T0) and this was significantly different $(P<0.05)$ from the 3 lowest-yielding treatments that all had milk yields of $13.7 \pm 0.3 \mathrm{~kg} /$ milking (FD30, FD90, and HV90). Milk yield per milking was similar to that in a recent study (16.7 and $10.4 \mathrm{~kg} /$ milking for early- and late-lactation cows, respectively) that analyzed premilking routines in high-yielding Holstein cows milked $3 \times$ daily in a commercial dairy herd (Watters et al., 2012). Milk yield per milking did not differ when comparing $60 \mathrm{~s}$ of manual stimulation to $60 \mathrm{~s}$ of vibration stimulation (Karch et al., 1988) or when comparing manual stimulation, no stimulation, and mechanical stimulation (Sagi et al., 1980b). Milk yield did not differ within classes of udder filling when comparing lag times of 0, 30, 45, and $60 \mathrm{~s}$ (Kaskous and Bruckmaier, 2011).

Average milk flow rate was $3.6 \pm 0.1 \mathrm{~kg} / \mathrm{min}$ and ranged from 3.2 to $3.7 \pm 0.1 \mathrm{~kg} / \mathrm{min}$ (in T0 and FD90 respectively; Table 2). All treatments had significantly higher $(P<0.05)$ average milk flow rates than T0. The observed average flow rate was very similar to the findings of Watters et al. (2012), who reported an average milk flow rate of $3.9 \mathrm{~kg} / \mathrm{min}$ for cows milked $3 \times$ daily

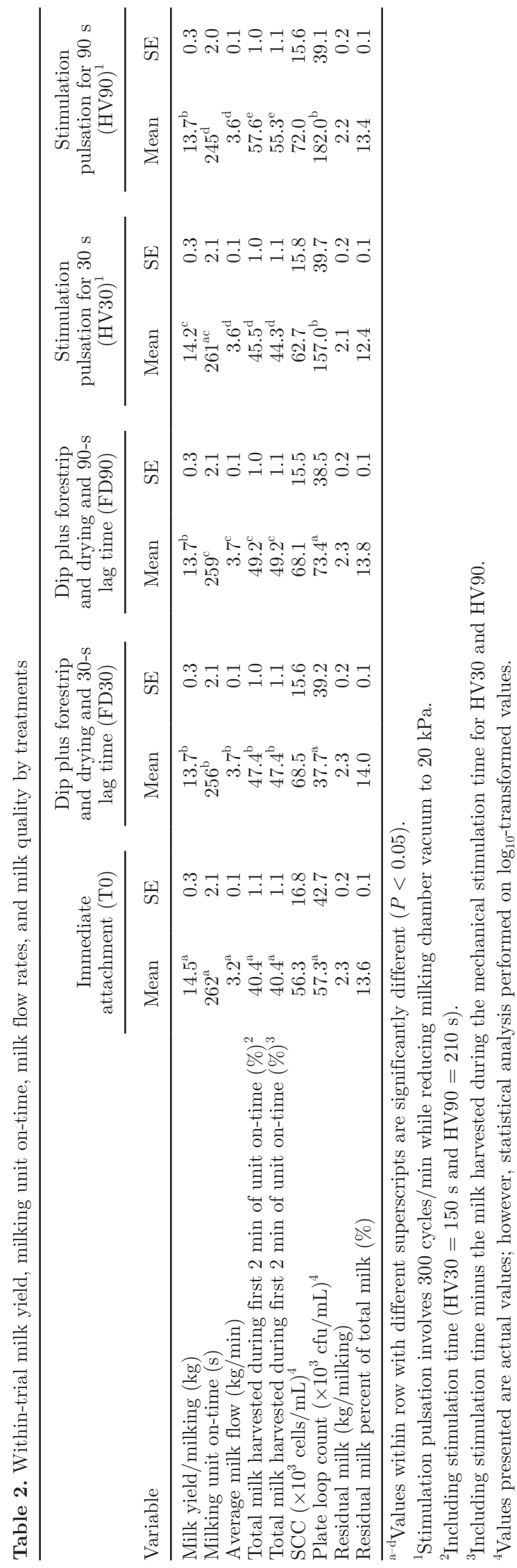


Table 3. Incidence of bimodal milk curves by treatment

\begin{tabular}{|c|c|c|}
\hline Treatment & $\begin{array}{l}\text { Total milk } \\
\text { curves }\end{array}$ & $\begin{array}{c}\text { Bimodal } \\
(\%)\end{array}$ \\
\hline Immediate attachment (T0) & 333 & $21^{\mathrm{a}}$ \\
\hline Dip plus forestrip and drying and $30 \mathrm{~s}$ lag time (FD30) & 347 & $14^{\mathrm{b}}$ \\
\hline Dip plus forestrip and drying and $90 \mathrm{~s}$ lag time (FD90) & 350 & $7^{\mathrm{c}}$ \\
\hline Stimulation pulsation for $30 \mathrm{~s}(\mathrm{HV} 30)^{1}$ & 337 & $14^{\mathrm{b}}$ \\
\hline Stimulation pulsation for $90 \mathrm{~s}(\mathrm{HV} 90)^{1}$ & 352 & $17^{\mathrm{ab}}$ \\
\hline
\end{tabular}

${ }^{a-c}$ Values within a column with different superscripts are significantly different $(P<0.05)$.

${ }^{1}$ Stimulation pulsation involves 300 cycles/min while reducing chamber vacuum to $20 \mathrm{kPa}$.

in a large commercial dairy farm. Previously, it was reported that an average milk flow rate was the lowest when no lag time was allowed in conjunction with low degrees of udder filling; however, with an udder filling of $>40 \%$, lag time had no effect on average milk flow rate (Kaskous and Bruckmaier, 2011). Kaskous and Bruckmaier (2011) reported that average milk flow rate did increase with each degree of udder filling category; however, significant differences were reported between lag times and milk flow rates only within the category of 20 to $40 \%$ udder filling. Sagi et al. (1980b) reported no difference in peak milk flow when comparing mechanical and manual stimulation (Sagi et al., 1980b). In the current study, average milk flow rate was lowest for high-vibration pulsation compared with manual stimulation. Weiss and Bruckmaier (2005) reported on the use of high-vibration pulsation that was applied for $0,20,40,60$, or $90 \mathrm{~s}$. As vibration time increased in this study, so did average milk flow rate (Weiss and Bruckmaier, 2005).

The incidence of bimodal milk curves, indicating delayed milk ejection and a transiently interrupted milk refill of the teat during the liner-closed phase, was highest for T0 (21\%) and lowest for FD90 (7\%; Table 3). The data indicate that the lowest (FD90) and second-highest (HV90) incidences of bimodal milk curves involved lag or stimulation time of $90 \mathrm{~s}$. It is possible that during the shift from stimulation mode into milk mode, a surge of milk creates a peak and then a valley, thus creating a bimodal milk curve. The small amount of milk $(0.32 \mathrm{~kg})$ harvested and $>55 \%$ of milk being harvested in the first 2 min for HV90 counters the idea that a high incidence of bimodal curves occurred for HV90. In our data, the bimodal milk curve calculation did not include the milk harvested during the mechanical stimulation phase. Our research is in agreement with previous studies indicating that 22 to $29 \%$ of cows with 0 -s lag had bimodal milk curves, whereas 5 to $6 \%$ of cows had bimodal milk curves when lag was $90 \mathrm{~s}$ (Watters et al., 2012). Sandrucci et al. (2007) recently also found a significant decrease in the incidence of bimodal milk curves when the premilking process included cleaning, forestripping, and dipping compared with cleaning alone or no premilking routine at all. In mid-lactation cows, bimodal milk curves occurred only with a stimulation time of $15 \mathrm{~s}$ that was followed by no latency period (Kaskous and Bruckmaier, 2011), suggesting that extent of udder fill may not be a concern in mid-lactation cows.

Mean SCC and PLC for all treatments were $66.1 \pm$ $11.9 \times 10^{3}$ cells $/ \mathrm{mL}$ and $102.4 \pm 20.4 \times 10^{3} \mathrm{cfu} / \mathrm{mL}$, respectively. The SCC did not significantly differ $(P>$ $0.05)$ between any of the treatments and ranged from $56.3 \pm 16.8 \times 10^{3}$ cells $/ \mathrm{mL}(\mathrm{T} 0)$ to $72.0 \pm 15.6 \times 10^{3}$ cells/mL (HV90; Table 2). It could be hypothesized that prestripping of milk would reduce SCC because the first streams of milk have higher SCC. Apparently, the number of cells in the stripped milk was not sufficient to affect total cell count in the milking. The PLC was lowest for FD30 (37.7 $\pm 39.2 \times 10^{3}$ cells $\left./ \mathrm{mL}\right)$ and highest for HV90 $\left(182.0 \pm 39.1 \times 10^{3}\right.$ cells $\left./ \mathrm{mL}\right)$, and these values differed significantly $(P<0.05)$. The PLC was expected to be higher for T0, HV30, and HV90 because no cleaning of the teats was performed before attachment of the milking machine. The PLC of 157 and $182 \times 10^{3} \mathrm{cfu} /$ $\mathrm{mL}$ for HV30 and HV90 could be explained by unit attachment before cleaning of the teats; however, the PLC for T0 was $57.3 \times 10^{3}$ cells $/ \mathrm{mL}$, which was significantly lower than that of HV30 and HV90.

Oxytocin concentration in blood was $<2.6 \mathrm{pg} / \mathrm{mL}$ for all treatments before stimulation, which agrees with previous data that indicated no activation of the milk ejection reflex if the oxytocin concentration is $<3.5 \mathrm{pg} / \mathrm{mL}$ (Figure 2). Cows on T0 had significantly higher oxytocin concentrations than cows on HV30 5 min before stimulation; however, the concentration of $2.57 \pm 0.2 \mathrm{pg} / \mathrm{mL}$ for $\mathrm{T} 0$ is lower than that required to elicit a milk ejection reflex (Figure 2). At time 0, the concentration of oxytocin for FD30 was $6.6 \mathrm{pg} /$ $\mathrm{mL}$, which indicated that cows on FD30 responded to manual stimulation and that oxytocin was released into the bloodstream. At 1 min after milking unit attachment, all treatments had blood oxytocin concentrations $>4.6 \mathrm{pg} / \mathrm{mL}$, which is within the range of 3 to $5 \mathrm{pg} / \mathrm{mL}$ in which the milk ejection reflex is initiated (Schams et al., 1984). Oxytocin concentrations for all treatments 


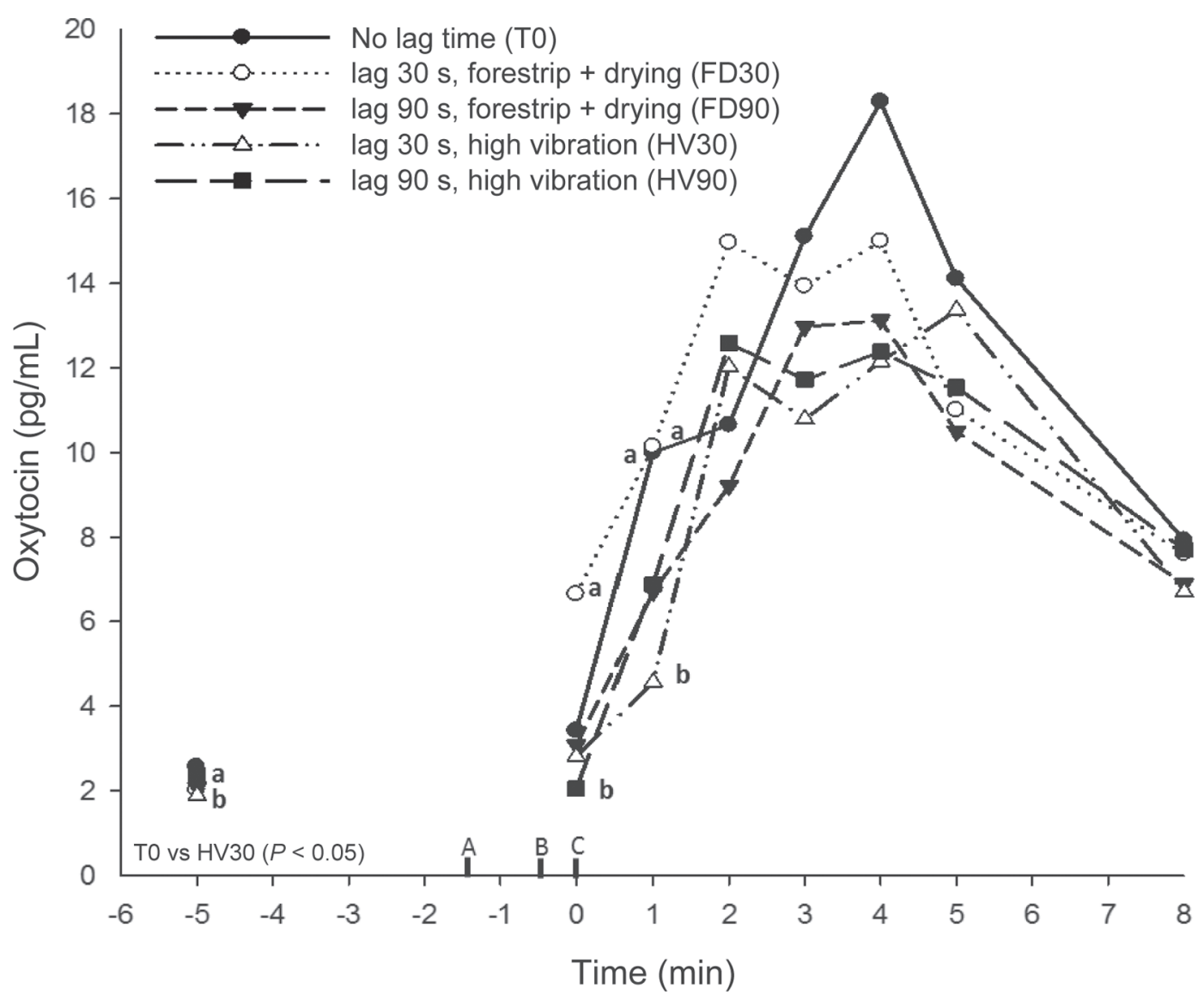

Figure 2. Oxytocin concentration ( $\mathrm{pg} / \mathrm{mL}$ ) before, during, and after milking for 5 treatments. Treatments were immediate attachment of the milking machine (T0; $\bullet$ ), dip plus forestrip and drying with 30-s lag time (FD30; O), dip plus forestrip and drying with 90-s lag time (FD90; $\mathbf{\nabla}$ ), high-vibration stimulation pulsation for $30 \mathrm{~s}(\mathrm{HV} 30 ; \Delta)$, and high-vibration stimulation pulsation for $90 \mathrm{~s}(\mathrm{HV} 90$; $\boldsymbol{\square})$. On $\mathrm{x}$-axis, A $=$ start of stimulation at $-90 \mathrm{~s}$ for FD90, B = start of stimulation at $-30 \mathrm{~s}$ for FD30, and $\mathrm{C}=$ start of stimulation at time zero for T0, HV30, and HV90. ${ }^{\mathrm{a}, \mathrm{b}}$ Means with different letters are significantly different $(P<0.05)$.

did not differ from 2 to 8 min after milking unit attachment. Stimulation did not occur until milking unit attachment for T0, HV30, and HV90, and oxytocin concentrations did not differ beyond 2 min, indicating that manual and mechanical stimulation elicit similar release of oxytocin. At $8 \mathrm{~min}$ after attachment of the milking unit, an intravenous injection of oxytocin was given to measure residual milk. The oxytocin concentration after $8 \mathrm{~min}$ did not differ between any of the treatments. One minute after oxytocin was administered intravenously, the concentration of oxytocin in the blood was $>450 \mathrm{pg} / \mathrm{mL}$. By 30 min postmilking, the concentration of oxytocin in blood was $<30 \mathrm{pg} / \mathrm{mL}$, indicating that oxytocin had been metabolized and the concentration was returning to near basal concentration. Our data are in agreement with previous data reporting that manual stimulation and stimulation by the milking machine elicit similar oxytocin profiles (Sagi et al., 1980a; Gorewit and Gassman, 1985).
Residual milk ranged from 2.1 to $2.3 \pm 0.2 \mathrm{~kg} / \mathrm{milk}-$ ing and did not differ among treatments (Table 2). Residual milk as a percentage of total milk (total milk $=$ milk yield + residual milk) was not different between treatments (Table 2). These observations are similar to those of Macuhova et al. (2003), who reported 14.8 to $15.9 \%$ residual milk when using mechanical methods for stimulation. Recent data suggest that $11 \%$ of total milk is left in the udder as residual milk (Belo et al., 2009). Negrão and Marnet (2006) classified crossbred and Holstein cows in into 2 groups based on residual milk yield, and they defined cows with $>8 \%$ residual milk as having impaired milk ejection. Residual milk as a percentage of total milk may be higher in the current study because the preset low-flow threshold was $1 \mathrm{~kg} /$ min. In addition, cows in our study were milked $3 \times$ daily and therefore may have less mammary pressure. Finally, breed, stage of lactation, and age all may influence the amount of residual milk. 


\section{CONCLUSIONS}

The use of high-vibration pulsation as a form of stimulation elicited a similar oxytocin release to that in cows subjected to manual stimulation. Milking unit on-time was lowest for cows given $90 \mathrm{~s}$ of high-vibration pulsation. Extending vibration stimulation to $90 \mathrm{~s}$ did not increase the amount of milk harvested in the first 2 min or reduce unit on-time significantly compared with other treatments. We conclude that the use of highvibration pulsation with increased cycles $(300 / \mathrm{min})$ and low vacuum is an adequate form of stimulation to initiate the milk ejection reflex. If only high-vibration pulsation is used, proper cleaning of the teats and detection of mastitis need further investigation because both high-vibration treatments showed significantly higher bacteria counts.

\section{ACKNOWLEDGMENTS}

We thank GEA Farm Technologies (Bönen, Germany) for their financial support and guidance during the experiment. Special thanks to the staff at the Cornell Dairy Teaching and Research Center (Ithaca, NY) for their assistance during the experiment. Special thanks to all the undergraduate research assistants for their help and support. The expert laboratory work by Yolande Zbinden (University of Bern, Switzerland) is gratefully acknowledged.

\section{REFERENCES}

Belo, C. J., S. Schlegel, J. Moll, E. Mostl, and R. M. Bruckmaier. 2009. Milk ejection disorders in Swiss dairy cows: a field study. J. Dairy Res. 76:222-228.

Bruckmaier, R. M., and J. W. Blum. 1996. Simultaneous recording of oxytocin release, milk ejection and milk flow during milking of dairy cows with and without prestimulation. J. Dairy Res. 63:201-208.

Bruckmaier, R. M., E. Rothenanger, and J. W. Blum. 1994. Measurement of mammary gland cistern size and determination of the cisternal milk fraction in dairy cows. Milchwissenschaft 49:543-546.

Bruckmaier, R. M., O. Wellnitz, and J. W. Blum. 1997. Inhibition of milk ejection in cows by oxytocin receptor blockade, alpha-adrenergic receptor stimulation and in unfamiliar surroundings. J. Dairy Res. 64:315-325.
Goff, K. R., and G. H. Schmidt. 1967. Effect of eliminating machine stripping of dairy cows on milk production, residual milk, and mastitis. J. Dairy Sci. 50:1787-1791.

Gorewit, R. C., and K. B. Gassman. 1985. Effects of duration of udder stimulation on milking dynamics and oxytocin release. J. Dairy Sci. $68: 1813-1818$.

Karch, G., H. Worstorff, A. Prediger, and F. Reinhardt. 1988. Stimulation capacity of the vibration system with special regard to the type of inflation. Milchwissenschaft 43:18-21.

Kaskous, S., and R. M. Bruckmaier. 2011. Best combination of prestimulation and latency period duration before cluster attachment for efficient oxytocin release and milk ejection in cows with low to high udder-filling levels. J. Dairy Res. 78:97-104.

Macuhova, J., V. Tancin, and R. M. Bruckmaier. 2003. Oxytocin release, milk ejection and milk removal in a multi-box automatic milking system. Livest. Prod. Sci. 81:139-147.

Negrão, J. A., and P. G. Marnet. 2006. Milk yield, residual milk, oxytocin and cortisol release during machine milking in Gir, Gir $\times$ Holstein and Holstein cows. Reprod. Nutr. Dev. 46:77-85.

Northeimer, W. W. 2001. Milk laboratory evaluation form: Standard plate count, coliform and simplified count methods. Form 2400a. Rev 2005. Food and Drug Administration, Washington, DC.

NRC. 2001. Nutrient Requirements of Dairy Cattle. 7th ed. Natl. Acad. Press, Washington, DC.

Sagi, R., R. C. Gorewit, W. G. Merrill, and D. B. Wilson. 1980a. Premilking stimulation effects on milking performance and oxytocin and prolactin release in cows. J. Dairy Sci. 63:800-806.

Sagi, R., R. C. Gorewit, and S. A. Zinn. 1980b. Milk ejection in cows mechanically stimulated during late lactation. J. Dairy Sci. 63:1957-1960.

Sandrucci, A., A. Tamburini, L. Bava, and M. Zucali. 2007. Factors affecting milk flow traits in dairy cows: Results of a field study. J. Dairy Sci. 90:1159-1167.

SAS Institute. 1999. User's Guide: Statistics. Version 8 ed. SAS Institute Inc., Cary, NC.

Schams, D. 1983. Oxytocin determination by radioimmunoassay. III. Improvement to subpicogram sensitivity and application to blood levels in cyclic cattle. Acta Endocrinol. (Copenh.) 103:180-183.

Schams, D., H. Mayer, A. Prokopp, and H. Worstorff. 1984. Oxytocin secretion during milking in dairy cows with regard to the variation and importance of a threshold level for milk removal. J. Endocrinol. 102:337-343.

Schmidt, G. H. 1972. Biology of Lactation. W. H. Freeman, San Francisco, CA.

Turner, H. 1955. Sources of variation in residual milk and fat in dairy cows: Their relation to secretion rates and persistency of lactation. Aust. J. Agric. Res. 6:514-529.

Watters, R. D., N. Schuring, H. N. Erb, Y. H. Schukken, and D. M. Galton. 2012. The effect of premilking udder preparation on Holstein cows milked 3 times daily. J. Dairy Sci. 95:1170-1176.

Weiss, D., and R. M. Bruckmaier. 2005. Optimization of individual prestimulation in dairy cows. J. Dairy Sci. 88:137-147.

Worstorff, H., A. Prediger, G. Karch, and H. Mayer. 1987. Function theory of mechanical prestimulation of dairy cows by vibration stimulation. Milchwissenschaft 42:353-356. 